\title{
NT-proBNP for Pulmonologists: Not Only a Rule-Out Test for Systolic Heart Failure but Also a Global Marker of Heart Disease
}

\author{
Siegfried Wieshammer ${ }^{\mathrm{a}}$ Jens Dreyhaupt ${ }^{c}$ Beate Basler $^{\mathrm{b}}$ Emil Marsovszky $^{\mathrm{a}}$ \\ a Medizinische Klinik I und ${ }^{b}$ Medizinische Klinik II, Klinikum Offenburg, Offenburg, und ${ }^{\mathrm{C} I n s t i t u t ~ f u ̈ r ~ B i o m e t r i e, ~}$ \\ Universität Ulm, Ulm, Deutschland
}

For editorial comment see p. 368

\section{Key Words}

Heart disease $\cdot$ Lung disease $\cdot$ Natriuretic peptide .

Dyspnea $\cdot$ Sensitivity and specificity

\begin{abstract}
Background: Recognizing heart disease is relevant to pulmonologists because many patients suspected to have dyspnea of pulmonary origin harbor heart disease. Objectives: To investigate the role of $\mathrm{N}$-terminal pro-brain natriuretric peptide (NT-proBNP) in identifying heart disease and cardiac causes of dyspnea among patients referred for evaluation by a pulmonologist. Methods: 697 consecutive outpatients (aged $57.5 \pm 16.4$ years) with chronic dyspnea prospectively underwent a diagnostic work-up for heart and lung diseases. Results: The prevalence of patients with heart disease was $25.3 \%$. The cardiac findings were placed into 6 groups which were associated with an increase in NT-proBNP in the following order: (1) left ventricular hypertrophy [regression coefficient $(\beta)=0.33, p=0.03$ ]; (2) exercise-induced myocardial ischemia ( $\beta=0.73, p=0.02$ ); (3) valvular or congenital heart disease or pericardial effusion ( $\beta=0.93, p<0.0001)$; (4) pulmonary hypertension ( $\beta=1.14, p<0.0001)$; (5) atrial fibrillation or left bundle branch block $(\beta=1.22, p<0.0001)$, and (6) left ventricular systolic dysfunction $(\beta=1.94, p<0.0001)$.
\end{abstract}

Using predefined cut-off values of $93 \mathrm{pg} / \mathrm{ml}$ (men) and 144 $\mathrm{pg} / \mathrm{ml}$ (women), sensitivity was 0.75 and specificity was 0.79 for identifying heart disease. The negative predictive value was 0.90 . If heart disease had to be considered as a cause of the dyspnea, sensitivity and the negative predictive value went up to 0.90 and 0.97 , respectively. Conclusions: NTproBNP performs well as a test for ruling out cardiac dyspnea. It is also useful as a rule-in test for heart disease, which enables the pulmonologist to appropriately select candidates for in-depth evaluation by cardiology.

Copyright $\odot 2009$ S. Karger AG, Basel

\section{Introduction}

A normal level of $\mathrm{N}$-terminal pro-brain natriuretic peptide (NT-proBNP) effectively rules out left ventricular systolic dysfunction in outpatients presenting with symptoms possibly due to heart failure who are referred from primary care to hospital-based cardiology services [1-4]. Dyspnea is the leading symptom of heart and lung disease. The referring physician's assessment determines whether a patient with dyspnea will be seen by a cardiologist or by a pulmonologist for further evaluation. NTproBNP may perform differently in pulmonary practice

\section{KARGER}

Fax +4161306 1234 E-Mail karger@karger.ch www.karger.com (c) 2009 S. Karger AG, Basel

0025-7931/09/0774-0370\$26.00/0

Accessible online at:

www.karger.com/res
Dr. S. Wieshammer

Medizinische Klinik I, Klinikum Offenburg

Ebertplatz 12, DE-77654 Offenburg (Germany)

Tel. +49 781472 2401, Fax +49781 4722402

E-Mail Siegfried.Wieshammer@og.ortenau-klinikum.de 
because the filtering action of the referring physicians results in differences between the 2 patient populations in terms of the prevalence and spectrum of heart disease [5]. Recognizing heart disease is relevant to the pulmonologist for 2 reasons. First, cardiac and pulmonary dyspneas are not always easy to distinguish. A number of patients referred with suspected pulmonary disease have dyspnea of cardiac origin. Second, many patients with known lung disease harbor concomitant heart disease, which may be masked by the lung-related dyspnea. This particularly applies to COPD $[6,7]$.

The modest specificity of NT-proBNP in identifying systolic heart failure is an everyday experience. The subsequent high rate of false-positive results undermines its diagnostic value in the view of many clinicians. There are, however, several other cardiac disorders, such as atrial fibrillation [8], valvular disease [9-11], left ventricular hypertrophy [12] and pulmonary hypertension [13, 14] that may also cause dyspnea and a rise in NT-proBNP. All these disorders reduce the specificity of NT-proBNP in identifying left ventricular systolic dysfunction, but NTproBNP would also be valuable to the pulmonologist as an indicator of the entire set of cardiological differential diagnoses. This marker should either reliably exclude a cardiac disorder or make it so probable that consulting a cardiologist would be worthwhile. We examined the value of NT-proBNP in detecting heart disease among patients referred for pulmonologist evaluation of dyspnea.

\section{Patients and Methods}

\section{Patients}

This prospective monocenter study was conducted on consecutive outpatients referred for evaluation of dyspnea of at least 2 weeks duration to the pulmonology service of an academic teaching hospital from January 2005 to January 2007. Dialysisdependent renal failure and information about a previous measurement of NT-proBNP were exclusion criteria. The study was approved by the ethics committee of the Baden-Württemberg State Chamber of Physicians. Informed consent was obtained.

\section{Diagnostic Procedures}

One physician (S.W.) examined the patients at their first visit. Blood samples were drawn for measurement of NT-proBNP (index test) using an ELISA assay, which was supplied free by the manufacturer (Roche Diagnostics, Mannheim, Germany). The company was not involved in the design of the study, the statistical analysis, and the preparation of the manuscript. The examining physicians were blinded to NT-proBNP values. The patients underwent a diagnostic work-up for heart and lung disease (reference test) within 10 days of the index test. The work-up included chest X-ray, pulmonary function tests, resting ECG, exercise ECG, and Doppler echocardiography. Further studies were done when indicated. One senior cardiologist (E.M.) did $94 \%$ of the echocardiograms. Treatment was not changed during the period from the index test to the reference test.

\section{Diagnostic Criteria}

Classification of Cardiological Findings

Left ventricular systolic function was graded into normal, and mildly, moderately or severely impaired. Pulmonary hypertension was diagnosed if the peak systolic gradient across the tricuspid valve measured with continuous wave Doppler was $\geq 35 \mathrm{~mm}$ $\mathrm{Hg}$. The severity of mitral or aortic regurgitation was graded into mild, moderate, or severe. The severity of aortic stenosis was graded by the mean transvalvular pressure gradient $(\Delta \mathrm{p})$ into mild ( $\Delta$ p 20-30 mm Hg), moderate $(\Delta \mathrm{p}>30-50 \mathrm{~mm} \mathrm{Hg})$, or severe $(\Delta \mathrm{p}>50 \mathrm{~mm} \mathrm{Hg})$. Left ventricular hypertrophy was diagnosed if the end-diastolic septal wall thickness was $\geq 12 \mathrm{~mm}$ or if the Sokolow criteria were fulfilled in the presence of arterial hypertension. A diagnosis of heart disease was only made on echocardiographic or ECG evidence and not on clinical or radiological grounds alone.

Relevant cardiological findings were prospectively defined and placed into 6 characteristic groups. Hierarchical categories were created to rank patients who had findings that fell within more than 1 characteristic group unambiguously:

Category 6: Impaired left ventricular systolic function (i.e. group 6).

Category 5: Atrial fibrillation or left bundle branch block (i.e. group 5) and no finding belonging to a higher category.

Category 4: Pulmonary hypertension (i.e. group 4) and no finding belonging to a higher category.

Category 3: At least mild aortic stenosis, at least moderate aortic regurgitation, at least moderate mitral regurgitation, severe tricuspid regurgitation, atrial septal defect, pericardial effusion (i.e. group 3) and no finding belonging to a higher category.

Category 2: Exercise-induced myocardial ischemia due to angiographically proven coronary disease (i.e. group 2) and no finding belonging to a higher category.

Category 1: Left ventricular hypertrophy (i.e. group 1) and no finding belonging to a higher category.

The patients with heart disease were classified as to whether the cardiological finding was thought to be (a) the principal cause of dyspnea, (b) a contributing factor, or (c) not related to the dyspnea. The presence of arterial hypertension or minor echocardiographic findings was also recorded. The latter included mild aortic regurgitation, mild mitral regurgitation and a borderline systolic pressure gradient of $30-34 \mathrm{~mm} \mathrm{Hg}$ across the tricuspid valve.

Classification of Lung Disease

Existing disease was classified as obstructive lung disease or as other disease. The former was classified as asthma and COPD. The degree of airway obstruction $\left(\mathrm{FEV}_{1} / \mathrm{VC}<5\right.$ th percentile) was stratified into 3 levels of severity based on the FEV $\mathrm{F}_{1}$ : mild to moderate $\left(\mathrm{FEV}_{1} \geq 60 \%\right.$ of predicted), moderately severe $\left(\mathrm{FEV}_{1} 50\right.$ $59 \%$ of predicted) or severe to very severe $\left(\mathrm{FEV}_{1}<50 \%\right.$ of predicted). The COPD patients were also classified according to the GOLD stages.

Data Analysis

The NT-proBNP values had a skewed distribution and therefore are presented as medians. The influence of all 6 cardiological 
Table 1. Cardiological findings and heart disease categories

\begin{tabular}{|c|c|c|c|c|c|c|c|}
\hline \multirow[t]{2}{*}{ Characteristic group } & \multirow[t]{2}{*}{$\mathrm{n}$} & \multicolumn{6}{|c|}{ Number of patients in heart disease category } \\
\hline & & 6 & 5 & 4 & 3 & 2 & 1 \\
\hline Impaired left ventricular systolic function (6) & 30 & 30 & & & & & \\
\hline Mild & 13 & & & & & & \\
\hline Moderate & 9 & & & & & & \\
\hline Severe & 8 & & & & & & \\
\hline Rhythm or conduction disturbances (5) & 51 & 7 & 43 & & & & \\
\hline Atrial fibrillation & 42 & & & & & & \\
\hline Left bundle branch block & 9 & & & & & & \\
\hline Pulmonary hypertension (4) & 61 & 12 & 6 & 43 & & & \\
\hline Valvular or congenital heart disease or pericardial effusion (3) & 26 & 4 & 5 & 3 & 14 & & \\
\hline Aortic regurgitation (moderate, severe) & $2(2,0)$ & & & & & & \\
\hline Aortic stenosis (mild, moderate, severe) & $11(10,0,1)$ & & & & & & \\
\hline Mitral regurgitation (moderate, severe) & $7(6,1)$ & & & & & & \\
\hline Severe tricuspid regurgitation without pulmonary hypertension & 3 & & & & & & \\
\hline Atrial septal defect & 1 & & & & & & \\
\hline Pericardial effusion & 2 & & & & & & \\
\hline Exercise-induced myocardial ischemia (2) & 12 & 3 & 1 & 1 & 1 & 6 & \\
\hline Left ventricular hypertrophy (1) & 66 & 5 & 8 & 10 & 3 & 0 & 40 \\
\hline
\end{tabular}

$\mathrm{n}$ is the number of cardiological findings in each characteristic group. The number of patients in the corresponding heart disease category is given at the top of each column. The numbers of patients with secondary cardiological findings are given lower down in each column. For example, left ventricular hypertrophy was present in 5 out of the 30 patients with impaired left ventricular function, 3 had exercise-induced myocardial ischemia, 4 had valvular or congenital heart disease or pericardial effusion, 12 had pulmonary hypertension and 7 had rhythm or conduction disturbances.

characteristic groups on NT-proBNP was assessed by multiple linear regression analysis after the NT-proBNP values had been transformed to their natural logarithm. Next, the groups were ranked according to their standardized regression coefficients, and the 6 heart disease categories were created as described above. A multiple linear regression model was used to investigate the effects of pulmonary disease groups and lung function parameters on NT-proBNP in the entire group and the impact of arterial hypertension and minor echocardiographic findings on NTproBNP in patients without heart disease. The effects of age, sex, interaction of age and sex, and body mass index (BMI) $[15,16]$ were simultaneously taken into account as confounding variables in all of the multiple linear regression models. Using previously defined cut-off values of $93 \mathrm{pg} / \mathrm{ml}$ for men and $144 \mathrm{pg} / \mathrm{ml}$ for women [17], sensitivity, specificity, predictive values and likelihood ratios for identifying heart disease categories 6, 5-6, 4-6, $3-6,2-6$ and $1-6$ and for identifying heart disease as a principal or contributory cause of dyspnea were calculated. Receiver operating characteristic (ROC) curves were constructed for both sexes and for different age and weight categories after dichotomizing the entire group by the median values for age and BMI in the group of patients with heart disease [18]. The values for area under the curve (AUC) with 95\% CIs were calculated and compared with each other [19]. Given the explorative nature of the study, no adjustment for multiple testing was made. $\mathrm{p}<0.05$ was considered to be significant. Analyses were performed using SAS, version 9.1 with the \%roc macro for ROC curve analysis.

\section{Results}

A total of 738 patients were enrolled in the study, 41 of whom had to be excluded because of incomplete data (missing NT-proBNP values, 3 patients; failure to turn up to the reference tests, 33 patients; incomplete reference tests, 5 patients), so that 697 patients ( 365 men and 332 women, mean age $57.5 \pm 16.4$ years) were eligible for analysis.

The prevalence of patients with sole cardiac disease was $5.9 \%$. Pulmonary disease was present in $78.6 \%$ of cases, either alone $(59.2 \%)$ or in combination with heart disease (19.4\%). There were 246 cardiological findings in the 176 patients with heart disease, as shown in table 1. Table 2 shows the baseline characteristics, comorbidities and the NT-proBNP values for each heart disease category. A total of 356 patients had asthma and 124 had COPD with the following distribution by GOLD stage: 5 had stage 1, 49 had stage 2, 36 had stage 3 and 34 had stage 4 . Heart disease was found in $43.5 \%$ of patients with COPD and left ventricular systolic function was impaired in $8.1 \%$ of patients with this condition. Of the 68 patients in the class 'other lung disease', 43 had interstitial lung dis- 


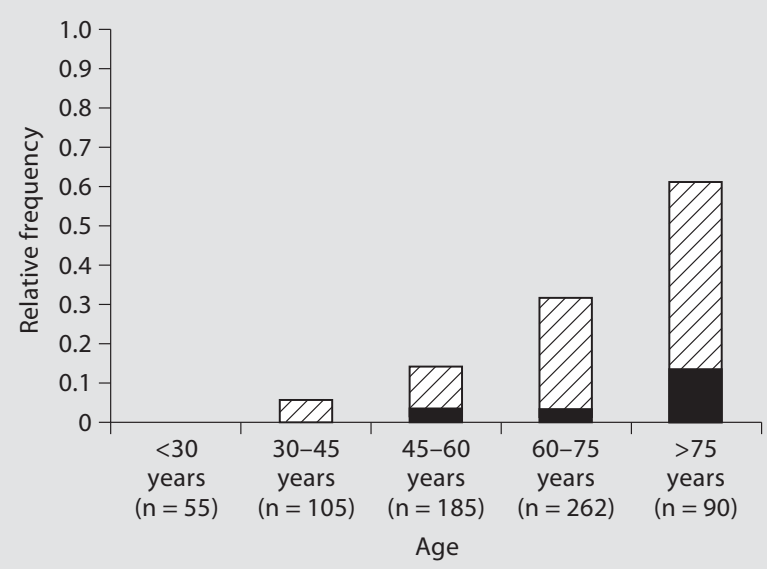

Fig. 1. Relative frequency of heart disease among the study population stratified by age. The black portion of each bar represents the frequency of patients with impaired left ventricular systolic function.

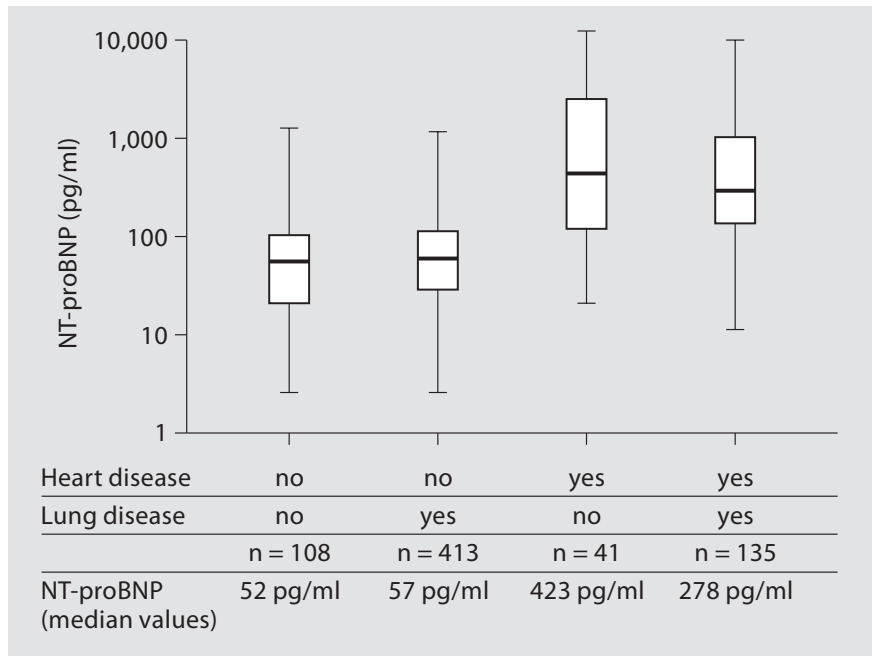

Fig. 2. Box-and-whisker plots of NT-proBNP levels among patients with dyspnea stratified by the presence of heart and lung disease. NT-proBNP levels are plotted on a logarithmic scale. The line within the box denotes the median. The box spans the interquartile range (25th-75th percentiles). The ends of the whiskers represent the minimum and maximum values.

ease and 12 had pneumoconiosis. Hypercapnic respiratory failure was present in 20 patients. The frequency of heart disease among the study population stratified by age is shown in figure 1 .

Women had higher NT-proBNP than men [regression coefficient $(\beta)=1.61,95 \%$ CI 1.02-2.19, $p<0.0001]$. Age

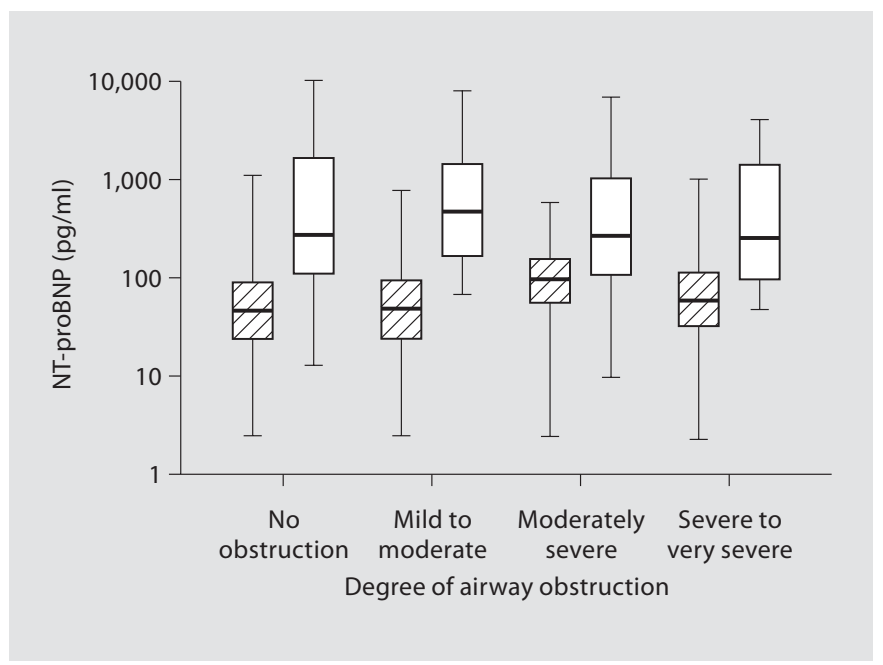

Fig. 3. Box-and-whisker plots of NT-proBNP levels stratified by the degree of airway obstruction in patients with (white box) and without (hatched box) concomitant heart disease. The degree of airway obstruction had no effect on NT-proBNP in either group. NT-proBNP levels are plotted on a logarithmic scale. The line within the box denotes the median. The box spans the interquartile range (25th-75th percentiles). The ends of the whiskers represent the minimum and maximum values.

$(\beta=0.04,95 \%$ CI $0.03-0.05, p<0.0001)$ and BMI $(\beta=$ $-0.03,95 \% \mathrm{CI}-0.04$ to $-0.01, \mathrm{p}<0.01)$ also influenced NT-proBNP.

Figure 2 illustrates that NT-proBNP was not affected by the presence of lung disease. A more detailed regression analysis revealed that the presence of asthma, COPD, other lung disease, hypercapnic respiratory failure, and the degree of airway obstruction had no independent effect on NT-proBNP. The relationship between the degree of airway obstruction and NT-proBNP is shown in figure 3.

All 6 cardiological characteristic groups were associated with an elevation of NT-proBNP. The following order was obtained from the standardized regression coefficients: (1) left ventricular hypertrophy ( $\beta=0.33,95 \%$ CI $0.03-0.62, \mathrm{p}=0.03)$; (2) exercise-induced myocardial ischemia $(\beta=0.73,95 \%$ CI 0.11-1.35, $p=0.02)$; (3) at least mild aortic stenosis, at least moderate aortic regurgitation, at least moderate mitral regurgitation, severe tricuspid regurgitation without evidence of pulmonary hypertension, atrial septal defect or pericardial effusion $(\beta=$ $0.93,95 \%$ CI $0.50-1.36, \mathrm{p}<0.0001)$; (4) pulmonary hypertension ( $\beta=1.14$, 95\% CI 0.84-1.44, $\mathrm{p}<0.0001)$; (5) atrial fibrillation or left bundle branch block $(\beta=1.22,95 \%$ 
Table 2. Clinical data, comorbidities and NT-proBNP levels in patients with and without heart disease

\begin{tabular}{|c|c|c|c|c|c|c|c|c|}
\hline & \multicolumn{7}{|l|}{ Heart disease } & \multirow{2}{*}{$\begin{array}{l}\text { No heart } \\
\text { disease } \\
(\mathrm{n}=521)\end{array}$} \\
\hline & $\begin{array}{l}\text { all patients } \\
(\mathrm{n}=176)\end{array}$ & $\begin{array}{l}\text { category } 6 \\
(\mathrm{n}=30)\end{array}$ & $\begin{array}{l}\text { category } 5 \\
(\mathrm{n}=43)\end{array}$ & $\begin{array}{l}\text { category } 4 \\
(n=43)\end{array}$ & $\begin{array}{l}\text { category } 3 \\
(\mathrm{n}=14)\end{array}$ & $\begin{array}{l}\text { category } 2 \\
(\mathrm{n}=6)\end{array}$ & $\begin{array}{l}\text { category } 1 \\
(\mathrm{n}=40)\end{array}$ & \\
\hline Male/female & $108 / 68$ & $25 / 5$ & $25 / 18$ & $18 / 25$ & $11 / 3$ & $6 / 0$ & $23 / 17$ & $257 / 264$ \\
\hline Mean BMI & $\begin{array}{l}28.8 \\
(19.4-54.5)\end{array}$ & $\begin{array}{l}28.7 \\
(20.1-54.5)\end{array}$ & $\begin{array}{l}28.3 \\
(20.1-43.7)\end{array}$ & $\begin{array}{l}28.6 \\
(19.4-46.9)\end{array}$ & $\begin{array}{l}27.9 \\
(20.8-34.4)\end{array}$ & $\begin{array}{l}27.2 \\
(23.3-29.8)\end{array}$ & $\begin{array}{l}30.2 \\
(23.5-41.0)\end{array}$ & $\begin{array}{l}27.2 \\
(15.6-55.1)\end{array}$ \\
\hline Mean age, years & $\begin{array}{l}69.6 \\
(36.0-87.2)\end{array}$ & $\begin{array}{l}70.9 \\
(48.4-85.7)\end{array}$ & $\begin{array}{l}69.9 \\
(49.8-85.4)\end{array}$ & $\begin{array}{l}70.5 \\
(38.2-86.1)\end{array}$ & $\begin{array}{l}66.2 \\
(36.0-81.2)\end{array}$ & $\begin{array}{l}73.3 \\
(68.2-77.1)\end{array}$ & $\begin{array}{l}67.9 \\
(44.9-87.2)\end{array}$ & $\begin{array}{l}53.4 \\
(14.0-84.3)\end{array}$ \\
\hline $\begin{array}{l}\text { Mean number of cardiological } \\
\text { findings }\end{array}$ & $\begin{array}{l}1.4 \\
(1-4)\end{array}$ & $\begin{array}{l}2.1 \\
(1-4)\end{array}$ & $\begin{array}{l}1.5 \\
(1-4)\end{array}$ & $\begin{array}{l}1.3 \\
(1-3)\end{array}$ & $\begin{array}{l}1.4 \\
(1-2)\end{array}$ & $\begin{array}{l}1.0 \\
(1-1)\end{array}$ & $\begin{array}{l}1.0 \\
(1-1)\end{array}$ & - \\
\hline Median NT-proBNP, pg/ml & $\begin{array}{l}291 \\
(10-11,584)\end{array}$ & $\begin{array}{l}2,144 \\
(68-11,584)\end{array}$ & $\begin{array}{l}548 \\
(20-5,966)\end{array}$ & $\begin{array}{l}423 \\
(30-5,350)\end{array}$ & $\begin{array}{l}234 \\
(18-9,242)\end{array}$ & $\begin{array}{l}586 \\
(60-1,399)\end{array}$ & $\begin{array}{l}114 \\
(10-1,740)\end{array}$ & $\begin{array}{l}55 \\
(2.5-1,148)\end{array}$ \\
\hline COPD & 54 & 10 & 8 & 19 & 5 & 3 & 9 & 70 \\
\hline Asthma & 64 & 10 & 20 & 10 & 8 & 0 & 16 & 292 \\
\hline Other lung disease & 17 & 2 & 6 & 7 & 0 & 0 & 2 & 51 \\
\hline Arterial hypertension & 126 & 21 & 27 & 25 & 11 & 3 & 39 & 178 \\
\hline
\end{tabular}

Figures in parentheses are minimum and maximum. See 'Patients and Methods' for explanations of the categories.

Table 3. Test characteristics of NT-proBNP in identifying different categories of heart disease and heart disease as the predominant or contributing cause of dyspnea

\begin{tabular}{llll}
\hline Heart disease & Sensitivity/specificity & $\begin{array}{l}\text { Positive predictive value/ } \\
\text { negative predictive value }\end{array}$ & $\begin{array}{c}\text { Positive likelihood ratio/ } \\
\text { negative likelihood ratio }\end{array}$ \\
\hline Category 6 & $0.97 / 0.68(1.00 / 0.68)$ & $0.12 / 1.00(0.12 / 1.00)$ & $3.04 / 0.05(3.15 / 0.00)$ \\
Category 5-6 & $0.86 / 0.72(0.97 / 0.71)$ & $0.26 / 0.98(0.24 / 1.00)$ & $3.03 / 0.19(3.35 / 0.05)$ \\
Category 4-6 & $0.84 / 0.75(0.94 / 0.74)$ & $0.40 / 0.96(0.36 / 0.99)$ & $3.37 / 0.22(3.65 / 0.09)$ \\
Category 3-6 & $0.83 / 0.77(0.93 / 0.75)$ & $0.45 / 0.95(0.38 / 0.99)$ & $3.54 / 0.22(3.73 / 0.09)$ \\
Category 2-6 & $0.83 / 0.77(0.92 / 0.76)$ & $0.47 / 0.95(0.40 / 0.98)$ & $3.64 / 0.22(3.80 / 0.10)$ \\
Category 1-6 & $0.75 / 0.79(0.90 / 0.78)$ & $0.55 / 0.90(0.48 / 0.97)$ & $3.58 / 0.32(4.06 / 0.13)$
\end{tabular}

The numbers in parentheses denote the test characteristics for identifying heart disease as a cause of dyspnea. Predefined NT-proBNP cut-off values were $93 \mathrm{pg} / \mathrm{ml}$ and $144 \mathrm{pg} / \mathrm{ml}$ for men and women, respectively. See 'Patients and Methods' for definition of heart disease categories.

CI $0.90-1.53, \mathrm{p}<0.0001)$, and (6) impaired left ventricular function $(\beta=1.94,95 \%$ CI 1.52-2.35, $\mathrm{p}<0.0001)$.

In the 521 patients without heart disease, arterial hypertension $(\mathrm{n}=178)$ had no effect on NT-proBNP $(82 \mathrm{pg} /$ $\mathrm{ml} v \mathrm{~s} .43 \mathrm{pg} / \mathrm{ml}, \mathrm{p}=0.07$ ). None of the minor echocardiographic findings was associated with NT-proBNP. The findings were: mild mitral regurgitation $(\mathrm{n}=46) 94$ vs. $49 \mathrm{pg} / \mathrm{ml}, \mathrm{p}=0.08$; mild aortic regurgitation $(\mathrm{n}=34) 116$ vs. $50 \mathrm{pg} / \mathrm{ml}, \mathrm{p}=0.07$; borderline systolic pulmonary artery pressure $(\mathrm{n}=10) 93 \mathrm{vs} .55 \mathrm{pg} / \mathrm{ml}, \mathrm{p}=0.83$; overall ( $\mathrm{n}=71) 95$ vs. $48 \mathrm{pg} / \mathrm{ml}, \mathrm{p}=0.06$. The interaction between arterial hypertension and minor echocardiographic findings had no effect on NT-proBNP $(\mathrm{p}=0.14)$. The presence of arterial hypertension or at least 1 minor echocardiographic finding $(\mathrm{n}=211)$ emerged as a predictor of NT-proBNP (83 vs. $41 \mathrm{pg} / \mathrm{ml}, \beta=0.25,95 \%$ CI $0.04-0.45, \mathrm{p}=0.02$ ).

Using cut-off values of $93 \mathrm{pg} / \mathrm{ml}$ for men and $144 \mathrm{pg} /$ $\mathrm{ml}$ for women [17], a sensitivity of 0.97 , a specificity of 0.68 and a positive predictive value of 0.12 were found when impaired left ventricular systolic function was required for the diagnosis of heart disease. Sensitivity went up to 1.00 after the criterion 'heart disease thought to be the principal or a contributory cause of the dyspnea' had been applied to the data. Table 3 shows that the positive predictive value strictly increased from 0.12 to 0.55 with more inclusive definitions of heart disease and from 0.12 to 0.48 if heart disease had to be considered as a cause of 
Table 4. Diagnostic value of NT-proBNP in detecting heart disease and identifying a cardiac cause of dyspnea in different age groups and in patients with COPD

\begin{tabular}{|c|c|c|c|c|c|}
\hline & \multicolumn{2}{|c|}{ Impaired left ventricular systolic function } & \multicolumn{3}{|c|}{ Any heart disease } \\
\hline & identified & missed & identified & missed & false-positive \\
\hline \multicolumn{6}{|l|}{ Age, years } \\
\hline $30-45(n=105)$ & $0(0)$ & $0(0)$ & $2(1)$ & $4(2)$ & $8(9)$ \\
\hline $45-60(n=185)$ & $6(6)$ & $1(0)$ & $15(13)$ & $10(2)$ & $23(25)$ \\
\hline $60-75(\mathrm{n}=262)$ & $9(9)$ & $0(0)$ & $63(55)$ & $24(5)$ & $57(65)$ \\
\hline$>75(\mathrm{n}=90)$ & $14(14)$ & $0(0)$ & $52(46)$ & $6(4)$ & $20(26)$ \\
\hline $\operatorname{COPD}(\mathrm{n}=124)$ & $10(10)$ & $0(0)$ & $41(38)$ & $13(3)$ & $31(34)$ \\
\hline
\end{tabular}

Data are numbers of patients. Given in parentheses are the numbers of patients in whom heart disease was thought to be the principal or a contributory cause of dyspnea. Predefined NT-proBNP cut-off values were $93 \mathrm{pg} / \mathrm{ml}$ and $144 \mathrm{pg} / \mathrm{ml}$ for men and women, respectively.

Table 5. Clinical assessment - heart disease as the cause of dyspnea

\begin{tabular}{|c|c|c|c|c|c|c|}
\hline \multirow{3}{*}{$\begin{array}{l}\text { Heart disease } \\
\text { category }\end{array}$} & \multicolumn{6}{|c|}{ Heart disease } \\
\hline & \multicolumn{2}{|c|}{ as principal cause } & \multicolumn{2}{|c|}{ as contributing factor } & \multicolumn{2}{|c|}{ not related to dyspnea } \\
\hline & $\begin{array}{l}\text { number of } \\
\text { patients }^{3}\end{array}$ & NT-proBNP & $\begin{array}{l}\text { number of } \\
\text { patients }^{3}\end{array}$ & NT-proBNP & $\begin{array}{l}\text { number of } \\
\text { patients }^{3}\end{array}$ & NT-proBNP \\
\hline $6(n=30)$ & $19(19)$ & $2,830(145,11,584)^{1}$ & $10(10)$ & $1,120(174,7407)^{1}$ & $1(0)$ & $68^{2}$ \\
\hline $5(\mathrm{n}=43)$ & $14(14)$ & $1,334(211,5,966)^{1}$ & $16(14)$ & $595(70,4,101)^{1}$ & $13(6)$ & $127(20,844)^{1}$ \\
\hline $4(\mathrm{n}=43)$ & $11(10)$ & $1,871(69,5,350)^{1}$ & $22(19)$ & $531(64,2,342)^{1}$ & $10(5)$ & $98(30,212)^{1}$ \\
\hline $3(\mathrm{n}=14)$ & $1(1)$ & $9,242^{2}$ & $6(5)$ & $236(52,3,483)^{1}$ & $7(5)$ & $194(18,507)^{1}$ \\
\hline $2(n=6)$ & $3(2)$ & $60,120,280^{2}$ & $3(3)$ & $891,1,218,1,399^{2}$ & $0(0)$ & \\
\hline $1(\mathrm{n}=40)$ & $12(7)$ & $171(44,944)^{1}$ & $11(11)$ & $235(127,1,740)^{1}$ & $17(1)$ & $66(10,129)^{1}$ \\
\hline Total $(\mathrm{n}=176)$ & $60(53)$ & $953(44,11584)^{1}$ & $68(62)$ & $544(52,7407)^{1}$ & $48(17)$ & $80(10,844)^{1}$ \\
\hline \multicolumn{7}{|c|}{$\begin{array}{l}{ }^{1} \text { NT-proBNP values are given as medians (min., max.). } \\
2 \text { NT-proBNP values are given as single values. } \\
{ }^{3} \text { The numbers included in brackets denote the numbers of patients with NT-proBNP levels above the predefined cut-off values ( } 93 \\
/ \mathrm{ml} \text { for men, } 144 \mathrm{pg} / \mathrm{ml} \text { for women). }\end{array}$} \\
\hline
\end{tabular}

dyspnea. The negative predictive values did not fall below 0.90 and 0.97 , respectively. The values for sensitivity and the negative predictive values were consistently higher if heart disease had to be considered as a cause of dyspnea. Table 4 illustrates the diagnostic performance of NTproBNP in various age groups and in the COPD cohort. Table 5 shows that the classification of heart disease as being either the principal cause, a contributing factor or not related to dyspnea is strongly reflected in NT-proBNP levels. Overall, $10.1 \%$ of the 128 patients with cardiac dyspnea and $25.0 \%$ of the 176 patients with heart disease had NT-proBNP levels below the cut-off. Sex-specific ROC curves for identifying heart disease and cardiac dyspnea are shown in figure 4 . The cut-off values providing the best trade-off between sensitivity and specificity were lower in men than in women. The cut-off values for identifying heart disease were lower than those for identifying cardiac dyspnea in both sexes (men 68 vs. 119 pg/ml, women 127 vs. $140 \mathrm{pg} / \mathrm{ml}$ ). The AUCs for detecting a cardiac dyspnea were higher than those for detecting heart disease both for men $(0.95$ vs. $0.88, \mathrm{p}<0.0001)$ and women $(0.90$ vs. $0.81, p<0.0001)$. Table 6 shows the effects of sex, age and BMI on NT-proBNP cut-off values and test operating characteristics at a predefined sensitivity of 


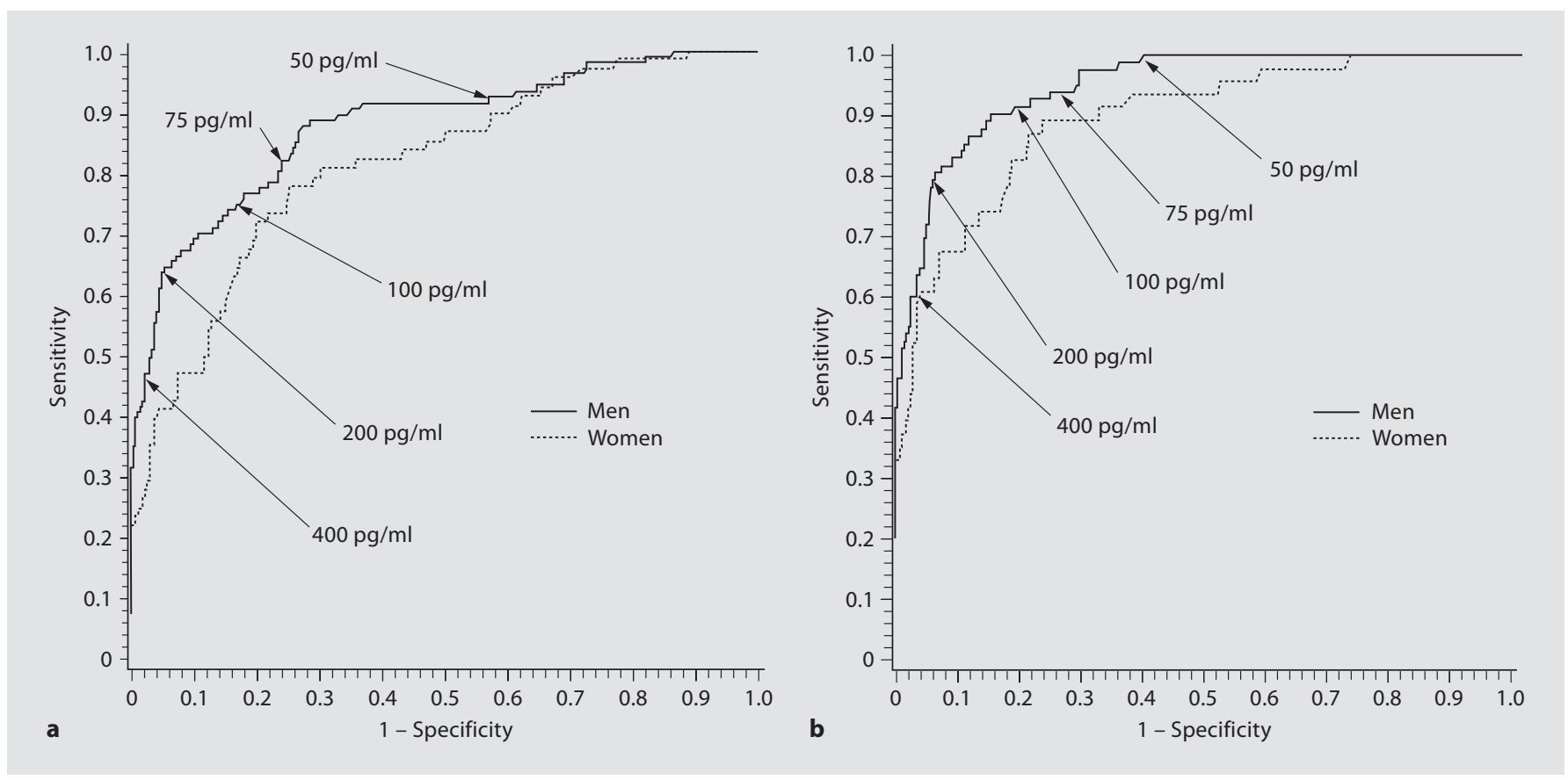

Fig. 4. a Sex-specific receiver operating characteristic (ROC) curves for the diagnostic performance of NTproBNP in identifying heart disease (heart disease categories 1-6). AUC is 0.88 (95\% CI $0.84-0.92$ ) for men $(\mathrm{n}=365)$ and $0.81(95 \%$ CI $0.75-0.87)$ for women $(\mathrm{n}=332)$ (n.s.). The cut-off values for maximal sensitivity and specificity are $68 \mathrm{pg} / \mathrm{ml}$ for men (sensitivity 0.88 , specificity 0.72 ) and $127 \mathrm{pg} / \mathrm{ml}$ for women (sensitivity 0.78 , specificity 0.75). b ROC curves for the diagnostic performance of NT-proBNP in identifying heart disease as the principal or contributory cause of dyspnea. AUC is 0.95 (95\% CI $0.93-0.97)$ for men and 0.90 (95\% CI 0.850.95) for women (n.s.). The cut-off values for maximal sensitivity and specificity are $119 \mathrm{pg} / \mathrm{ml}$ for men (sensitivity $0.90 \%$, specificity $0.85 \%$ ) and $140 \mathrm{pg} / \mathrm{ml}$ for women (sensitivity $0.89 \%$, specificity $0.77 \%$ ).

0.90. The difference between cut-off values for detecting cardiac dyspnea was small between men and women (119 vs. $111 \mathrm{pg} / \mathrm{ml}$ ) and both age groups (111 vs. $128 \mathrm{pg} / \mathrm{ml})$, whereas the difference between the 2 weight categories was larger (160 vs. $102 \mathrm{pg} / \mathrm{ml}$ ). Figure 5 shows the estimated density and distribution functions of NT-proBNP for patients with and without heart disease.

\section{Discussion}

The use of NT-proBNP has gained a wide acceptance in differentiating heart failure from lung disease in patients presenting with acute dyspnea [20-23]. This is the first study to investigate the role of NT-proBNP in the pulmonologist work-up of patients with chronic dyspnea. As a consequence of the filtering action of the referring physicians, the percentage of patients with sole cardiac disease was only $5.9 \%$. Of note however, about 1 in 4 patients with lung disease had concomitant heart disease.
Our study confirmed that NT-proBNP performs well as a test for ruling out an impaired left ventricular systolic function in a population with a low prevalence of that disorder. The more important finding was that it was not only impaired left ventricular systolic function but all of the cardiological characteristic groups that were associated with an elevated NT-proBNP. The monotonic decrease in sensitivity and the inverse behavior of the values for specificity shown in table 3 mirror the ranking order derived from the standardized regression coefficients. From this it can be concluded that the pulmonologist may use NT-proBNP to identify an array of cardiac disorders. We found no independent effect of lung disease on NTproBNP, which agrees with a study by Mogelvang et al. [24].

It was common for the patients with heart disease to have more than 1 cardiological finding. The hierarchical disease categories used in this study are not intended as a staging system. They should be regarded as a pragmatic way to make a long list of findings statistically manage- 


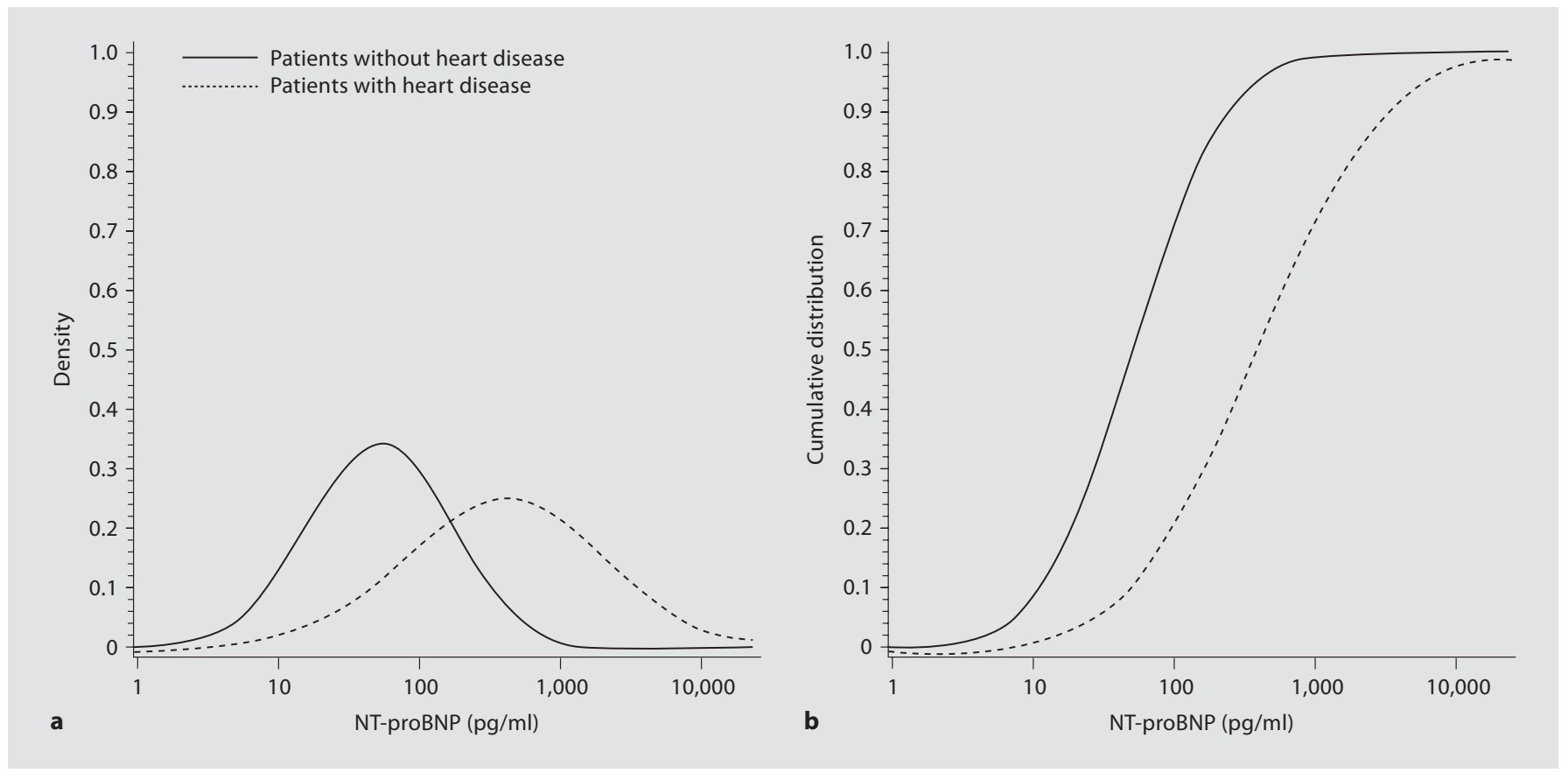

Fig. 5. a Estimated density functions of NT-proBNP for patients with and without heart disease. b Estimated distribution functions of NT-proBNP in patients with and without heart disease. NT-proBNP levels are plotted on a logarithmic scale.

Table 6. Cut-off values of NT-proBNP, specificity, and predictive values as determined from the ROC curves for identifying heart disease and cardiac dyspnea in different sex, age and weight categories. Sensitivity was held constant at 0.90

\begin{tabular}{|c|c|c|c|c|c|c|}
\hline & \multicolumn{2}{|l|}{ Sex } & \multicolumn{2}{|l|}{ Age } & \multicolumn{2}{|l|}{ BMI } \\
\hline & $\begin{array}{l}\text { male } \\
(\mathrm{n}=365)\end{array}$ & $\begin{array}{l}\text { female } \\
(n=332)\end{array}$ & $\begin{array}{l}\leq 71.7 \text { years } \\
(\mathrm{n}=544)\end{array}$ & $\begin{array}{l}>71.7 \text { years } \\
(n=153)\end{array}$ & $\begin{array}{l}\leq 28.4 \\
(n=421)\end{array}$ & $\begin{array}{l}>28.4 \\
(n=276)\end{array}$ \\
\hline NT-proBNP cut-off value, $\mathrm{pg} / \mathrm{ml}$ & $59(119)$ & $63(111)$ & $38(111)$ & $78(128)$ & $72(160)$ & $50(102)$ \\
\hline Specificity & $0.67(0.85)$ & $0.42(0.67)$ & $0.43(0.81)$ & $0.21(0.50)$ & $0.62(0.84)$ & $0.51(0.73)$ \\
\hline Positive predictive value & $0.53(0.63)$ & $0.29(0.31)$ & $0.23(0.35)$ & $0.61(0.62)$ & $0.38(0.53)$ & $0.46(0.48)$ \\
\hline Negative predictive value & $0.94(0.97)$ & $0.94(0.98)$ & $0.96(0.99)$ & $0.61(0.85)$ & $0.96(0.98)$ & $0.91(0.96)$ \\
\hline
\end{tabular}

The NT-proBNP cut-off values and the test operating characteristics referring to the identification of cardiac dyspnea are shown in parentheses.

able. This approach fits with the suggested role of NTproBNP in the work-up of dyspnea by the pulmonologist who is not concerned with issues such as identifying specific heart diseases and assessing their severity. Recommending a laboratory test as a diagnostic tool for detecting atrial fibrillation or left bundle branch block may seem quite contentious to cardiologists and chest physicians, but a pulmonologist work-up of dyspnea usually does not include electrocardiography [25]. Accordingly, this study was not designed to assess the extent to which NT-proBNP added value beyond electrocardiography but to evaluate its role as a diagnostic tool in its own right.

We attempted to avoid making diagnoses of doubtful significance by excluding mild aortic and mild mitral regurgitation from the characteristic groups and by setting the threshold for the peak systolic pressure gradient 
across the tricuspid valve at $35 \mathrm{~mm} \mathrm{Hg}$. A gradient of 30 $\mathrm{mm} \mathrm{Hg}$ is considered as the upper limit of normal [26]. Identifying left ventricular hypertrophy in patients with normal systolic function is clearly relevant, because this condition is associated with an increased risk of cardiac death [12]. After systolic dysfunction, the group 'rhythm and conduction disturbances', which mainly consisted of patients with atrial fibrillation, had the greatest impact on NT-proBNP. Wang et al. [8] also observed a strong association between atrial fibrillation and NT-proBNP. As to the effect of myocardial ischemia, our findings are difficult to compare with other studies, because dyspnea rather than angina or a positive exercise test was the criterion for entry [27]. The response of NT-proBNP secretion to ischemic episodes causing dyspnea may differ from the response to ischemia presenting as angina pectoris [28]. A number of participants without heart disease had an elevated NT-proBNP. Arterial hypertension and minor echocardiographic findings might partly account for this observation, because the presence of arterial hypertension or at least 1 minor echocardiographic finding had an effect on NT-proBNP. Left ventricular diastolic dysfunction may be another factor. Many of our patients with normal systolic function and left ventricular hypertrophy, atrial fibrillation, left bundle branch block or pulmonary hypertension probably had diastolic dysfunction. It is to be assumed, however, that not all the patients with this condition were included in the characteristic groups.

The prerequisite for entering this study was dyspnea so that all the patients had at least 1 appropriate symptom of heart disease. Detecting a cardiac abnormality does not imply, however, that it is a cause of dyspnea, so patients were clinically classified as to whether the cardiological finding was thought to be a cause of dyspnea. The AUCs presented in figure 4 show that NT-proBNP has a powerful discriminatory ability to identify cardiac dyspnea. The AUCs and the data given in tables 3-5 indicate that NT-proBNP performs better as a test for identifying cardiac dyspnea than for detecting cardiac abnormalities. This was expected, because heart disease causing dyspnea is more likely to be associated with increases in myocardial wall stress or stiffness, which are thought to be the principal triggers of proBNP release [29].

The predefined goal of this study was to prospectively evaluate the gender-specific cut-off values proposed by Nielsen et al. [17] for a pulmonologist's work-up of chronic dyspnea, which are lower than those recommended in the setting of acute dyspnea [29]. The patients of the Nielsen et al. study were recruited from primary care physicians who were asked to refer patients with dyspnea for a diagnostic work-up for both heart and lung disease. Those authors found a sensitivity of 0.95 and a specificity of 0.68 in a study population with a prevalence of heart failure of $23 \%$. These values agree well with the test characteristics found in our study, when impaired left ventricular systolic function was required for the diagnosis of heart disease. Mogelvang et al. [24] established ageand sex-specific limits to discriminate between cardiac and pulmonary causes of dyspnea in the general population. Rutten et al. [30] recommended a gender-independent optimal cut-off value of $125 \mathrm{pg} / \mathrm{ml}$ for identifying heart failure among elderly patients with COPD. Gustafsson et al. [2] found no improvement in diagnostic performance when age-differentiated cut-off values were used in patients who had been referred from primary care with suspected heart failure. Age, sex and BMI are predictors of NT-proBNP, but the application of sex-, age- and BMIspecific cut-off values to the individual patient would make the clinical use of NT-proBNP rather unwieldy. Fundamental to the value of a screening test for cardiac dyspnea is a high sensitivity, which translates into a low risk of overlooking a patient with this condition. The data presented in table 6 suggest that a cut-off value of $100 \mathrm{pg} /$ ml entails sensitivity values above $90 \%$ for men and women as well as for both age and weight categories. The negative predictive value of 0.85 found in the older age category should be considered in the context of the low specificity in this cohort. Of note is that no patient with symptomatic left ventricular systolic dysfunction was misclassified when this cut-off value was used, as shown in table 5. Although medical decision-making often revolves around cut-off values, it is important to recognize that NT-proBNP is a continuous variable. The frequency of heart disease increases with rising levels of NTproBNP, so that NT-proBNP may serve as a rule-in test of heart disease. Our findings support this concept [31, 32]. Figure 5 may provide guidance for selecting operating points for particular clinical situations.

Pulmonologists should not dismiss the use of NTproBNP as diagnostic sidetracking because heart disease often contributes to the presenting complaint, even in patients with a known pulmonary cause of dyspnea. In this study, more than 2 out of 5 patients with COPD had a relevant cardiological finding. Further, heart disease is a major cause of death among patients with lung disease [33] and NT-proBNP provides prognostic information [8, 34]. The importance of dyspnea as an indicator of risk was emphasized by Abidov et al. [35] in a study on elderly patients referred for cardiac stress testing. Patients with 
no known history of coronary disease who reported dyspnea and no chest pain had more than twice the risk of cardiac death compared to patients with typical angina. One conclusion to be drawn from this study is that the cause of dyspnea should be pursued vigorously. Our findings suggest that measurement of NT-proBNP is useful to the pulmonologist as a first step in achieving this goal. The pulmonologist should proceed with an in-depth evaluation by cardiology irrespective of the pulmonary status in elderly patients with an elevated NT-proBNP and whose cardiac status has not yet been determined. At the other end of the scale, cardiac disorders are so uncommon in patients under 45 years of age that the measurement of NT-proBNP will hardly ever be useful for this group.

The following limitations deserve comment. First, placing disparate cardiological findings into a set of 6 groups is somewhat arbitrary. This particularly applies to group 3, because pericardial effusion, atrial septal defect and different types of valvular heart disease have little in common. As shown in table 1, the numbers of patients with these conditions were too low for any attempts to analyze different types of disease separately. Pericardial effusion may cause a low NT-proBNP state, because the myocardial wall is not abnormally stressed despite symptoms of heart failure [31]. On the other hand, none of these disorders can be ignored in a study like this. Second, echocardiography is observer-dependent and imprecise. In everyday practice, however, echocardiography is the gold standard to which the performance of NT-
proBNP must be compared. Third, ergometry was used to detect myocardial ischemia. It is to be assumed that some patients with this condition had to stop the exercise test due to lung-related dyspnea. This further reduces its limited sensitivity so that the prevalence of ischemia was underestimated. Finally, left ventricular diastolic function was not analyzed. Assessment of transmitral flow velocity curves by Doppler echocardiography has many limitations and is unable to provide unequivocal evidence of diastolic dysfunction [36]. Tissue Doppler imaging is superior to conventional Doppler echocardiography, but this technique was not available to us [37].

In conclusion, this study shows that NT-proBNP has a powerful diagnostic ability to identify those with cardiac dyspnea among patients with chronic dyspnea referred to a pulmonologist for evaluation, if cut-off values of $93 \mathrm{pg} /$ $\mathrm{ml}$ for men and $144 \mathrm{pg} / \mathrm{ml}$ for women are used. A genderindependent cut-off value of $100 \mathrm{pg} / \mathrm{ml}$ might be a useful alternative. The potential of NT-proBNP is not exhausted if the diagnostic target is narrowed to ruling out left ventricular systolic dysfunction. Rather, NT-proBNP should be considered as a global indicator of heart disease. Elevated NT-proBNP levels help the pulmonologist to rule in heart disease so that candidates for in-depth evaluation by cardiology can be appropriately selected. Given the high prevalence of heart disease among elderly patients referred for pulmonologist evaluation of dyspnea, NT-proBNP should be added to the diagnostic work-up of patients whose cardiac status has not yet been determined.

\section{References}

1 Cowie MR, Struthers AD, Wood DA, Coats AJS, Thompson SG, Poole-Wilson PA, Sutton GC: Value of natriuretic peptides in assessment of patients with possible new heart failure in primary care. Lancet 1997;350: 1347-1351.

-2 Gustafsson F, Steensgaard-Hansen F, Badskjaer J, Poulsen AH, Corell P, Hildebrandt $P$ : Diagnostic and prognostic performance of N-terminal proBNP in primary care patients with suspected heart failure. J Card Fail 2005;11(suppl 5):S15-S20.

$\checkmark 3$ Zaphiriou A, Robb S, Murray-Thomas T, Mendez G, Fox, K, McDonagh T, Hardman SMC, Dargie HJ, Cowie MR: The diagnostic accuracy of plasma BNP and NTproBNP in patients referred from primary care with suspected heart failure: results of the UK natriuretic peptide study. Eur J Heart Fail 2005; 7:537-541.
4 Wright SP, Doughty RN, Pearl A, Gamble GD, Whalley GA, Walsh HJ, Gordon G, Bagg W, Oxenham H, Yandle T, Richards $M$, Sharpe N: Plasma amino-terminal pro-brain natriuretic peptide and accuracy of heartfailure diagnosis in primary care. A randomized, controlled trial. J Am Coll Cardiol 2003;42:1793-1800.

5 Moons KGM, Harrell FE: Sensitivity and specificity should be de-emphasized in diagnostic accuracy studies. Acad Radiol 2003; 10:670-672.

6 Rutten FH, Cramer MJM, Grobbee DE, Sachs APE, Kirkels JH, Lammers JWJ, Hoes AW: Unrecognized heart failure in elderly patients with stable chronic obstructive pulmonary disease. Eur Heart J 2005;26:18871894.
7 Curkendall SM, DeLuise C, Jones JK, Lanes S, Stang MR, Goehring E, She D: Cardiovascular disease in patients with chronic obstructive pulmonary disease, Saskatchewan Canada cardiovascular disease in COPD patients. Ann Epidemiol 2006;16:63-70.

$\rightarrow 8$ Wang TJ, Larson MG, Levy D, Benjamin EJ, Leip EP, Omland T, Wolf PA, Vasan RS: Plasma natriuretic peptide levels and the risk of cardiovascular events and death. N Engl J Med 2004;350:655-663.

$>9$ Sutton TM, Stewart RA, Gerber IL, West TM, Richards AM, Yandle TG, Kerr AJ: Plasma natriuretic peptide levels increase with symptoms and severity of mitral regurgitation. J Am Coll Cardiol 2003;41:2280-2287. 
10 Weber M, Hausen M, Arnold R, Moellmann $\mathrm{H}, \mathrm{Nef} \mathrm{H}$, Elsaesser A, Mitrovic V, Hamm C: Diagnostic and prognostic value of N-terminal pro B-type natriuretic peptide (NTproBNP) in patients with chronic aortic regurgitation. Int J Cardiol 2008;127:321-327.

- 11 Weber M, Arnold R, Rau M, Brandt R, Berkovitsch A, Mitrovic V, Hamm C: Relation of $\mathrm{N}$-terminal pro-B-type natriuretic peptide to severity of valvular aortic stenosis. Am J Cardiol 2004;94:740-745.

-12 Olsen MH, Wachtell K, Tuxen C, Fossum E, Bang LE, Hall C, Ibsen H, Rokkedal J, Devereux RB, Hildebrandt P: N-terminal probrain natriuretic peptide predicts cardiovascular events in patients with hypertension and left ventricular hypertrophy: a LIFE study. J Hypertens 2004;22:1597-1604.

13 Bando M, Ishii Y, Sugiyama Y, Kitamura S: Elevated plasma brain natriuretic peptide levels in chronic respiratory failure with cor pulmonale. Respir Med 1999;93:507-514.

14 Ishii J, Nomura M, Ito M, Naruse H, Mori Y, Wang J, Ishikawa T, Kurokawa H, Kondo T, Nagamura Y, Ezaki K, Watanabe Y, Hishida H: Plasma concentration of brain natriuretic peptide as a biochemical marker for the evaluation of right ventricular overload and mortality in chronic respiratory disease. Clin Chim Acta 2000;301:19-30.

15 Wang TJ, Larson MG, Levy D, Leip EP, Benjamin EJ, Wilson PWF, Sutherland P, Omland T, Vasan RS: Impact of age and sex on plasma natriuretic peptide levels in healthy adults. Am J Cardiol 2002;90:254-258.

$\checkmark 16$ Mehra MR, Uber PA, Park MH, Scott RL, Ventura HO, Harris BC, Frohlich ED: Obesity and suppressed B-type natriuretic peptide levels in heart failure. J Am Coll Cardiol 2004;43:1590-1595.

-17 Nielsen LS, Svanegaard J, Klitgaard NA, Egeblad H: N-terminal pro-brain natriuretic peptide for discriminating between cardiac and non-cardiac dyspnoea. Eur J Heart Fail 2004;6:63-70.

18 Bewick V, Cheek L, Ball J: Statistics review 13: receiver operating characteristic curves. Critical Care 2004;8:508-512.

19 Hanley JA, McNeill BJ: A method of comparing the areas under receiver operating characteristic curves derived from the same cases. Radiology 1983;148:839-843.

20 Maisel AS, Krishnaswamy P, Nowak RM, McCord J, Hollander JE, Duc P, Omland T, Storrow AB, Abraham WT, Wu AH, Clopton P, Steg PG, Westheim A, Knudsen CW, Perez A, Kazanegra R, Herrmann HC, McCullough PA; Breathing Not Properly Multinational Study Investigators: Rapid measurement of B-type natriuretic peptide in the emergency diagnosis of heart failure. N Engl J Med 2002; 347:161-167.
21 Januzzi JL, van Kimmenade R, Lainchbury J, Bayes-Genis A, Ordonez-Llanos J, SantaloBel M, Pinto YM, Richards M: NT-proBNP testing for diagnosis and short-term prognosis in acute destabilized heart failure: an international pooled analysis of 1256 patients. The International Collaborative of NTproBNP Study. Eur Heart J 2006;27:330337.

22 Mueller C, Scholer A, Laule-Kilian K, Schindler MB, Buser P, Pfisterer M, Perruchoud AP: Use of B-type natriuretic peptide in the evaluation and management of acute dyspnea. N Engl J Med 2004;350:647654.

23 Moe GW, Howlett J, Januzzi JL, Zowall H; for the Canadian multicenter improved management of patients with congestive heart failure (IMPROVE-CHF) study investigators: N-terminal pro-B-type natriuretic peptide testing improves the management of patients with suspected acute heart failure: primary results of the Canadian prospective randomized multicenter IMPROVE-CHF study. Circulation 2007;115:3103-3110.

24 Mogelvang R, Goetze JP, Schnohr P, Lange P, Sogaard P, Rehfeld JF, Jensen JS: Discriminating between cardiac and pulmonary dysfunction in the general population with dyspnea by plasma pro-B-type natriuretic peptide. J Am Coll Cardiol 2007;50:16941701.

25 Davie AP, Francis CM, Love MP, Caruana L, Starkey IR, Shaw TR, Sutherland GR, McMurray JJ: Value of the electrocardiogram in identifying heart failure due to left ventricular systolic dysfunction. BMJ 1996 27;312: 222.

26 Aessopos A, Farmakis D, Taktikou H, Loukopoulos D: Doppler-determined peak systolic tricuspid pressure gradient in persons with normal pulmonary function and tricuspid regurgitation. J Am Soc Echocardiogr 2000;13:645-649.

-27 Chatha K, Alsoud M, Griffiths MJ, Elfatih A, Abozguia K, Horton RC, Dunmore SJ, Gama $\mathrm{R}$ : B-type natriuretic peptide in reversible myocardial ischaemia. J Clin Pathol 2006;59: 1216-1217.

28 Cheng TO: Acute dyspnea on exertion is an angina equivalent. Int J Cardiol 2007;115: 116.

29 Mueller C, Breidthardt T, Laule-Kilian K, Christ M, Perruchoud AP: The integration of BNP and NT-proBNP into clinical medicine. Swiss Med Wkly 2007;137:4-12.
30 Rutten FH, Cramer MJM, Zuithoff NPA, Lammers JWJ, Verweij W, Grobbee DE, Hoes AW: Comparison of B-type natriuretic peptide assays for identifying heart failure in stable elderly patients with a clinical diagnosis of chronic obstructive pulmonary disease. Eur J Heart Fail 2007;9:651-659.

- 31 Maisel A, Mueller C, Adams K Jr, Anker SD, Aspromonte N, Cleland JGF, Cohen-Solal A, Dahlstrom U, DeMaria A, Di Somma S, Filippatos GS, Fonarow GC, Jourdain P, Komajda M, Liu PP, McDonagh T, McDonald K, Mebazaa A, Nieminen MS, Peacock WF, Tubaro M, Valle R, Vanderhyden $M$, Yancy CW, Zannad F, Braunwald E: State of the art: using natriuretic peptide levels in clinical practice. Eur J Heart Fail 2008; 10: 824-839.

-32 Rutten FH, Hoes AW: B-type natriuretic peptide assays for detecting heart failure in the elderly: same value as those in the younger? Int J Cardiol 2008;125:161-165.

-33 Salpeter SR, Ormiston TM, Salpeter EE: Cardiovascular effects of $\beta$-agonists in patients with asthma and COPD: a meta-analysis. Chest 2004;125:2309-2321.

- 34 Groenning BA, Raymond I, Hildebrandt PR, Nilsson JC, Baumann M, Pedersen F: Diagnostic and prognostic evaluation of left ventricular systolic heart failure by plasma $\mathrm{N}$ terminal pro-brain natriuretic peptide concentrations in a large sample of the general population. Heart 2004;90:297-303.

- 35 Abidov A, Rozanski A, Hachamovitch R, Hayes SW, Aboul-Enein F, Cohen I, Friedman JD, Germano G, Berman DS: Prognostic significance of dyspnea in patients referred for cardiac stress testing. N Engl J Med 2005;353:1889-1898.

-36 Yamaguchi H, Yoshida J, Yamamoto K, Sakata Y, Mano T, Akehi N, Hori M, Lim YJ, Mishima M, Masuyama T: Elevation of plasma brain natriuretic peptide is a hallmark of diastolic heart failure independent of ventricular hypertrophy. J Am Coll Cardiol 2004;43:55-60.

-37 Paulus WJ, Tschöpe C, Sanderson JE, Rusconi C, Flachskampf FA, Rademakers FE, Marino P, Smiseth OA, De Keulenaer G, Leite-Moreira AF, Borbély A, Edes I, Handoko ML, Heymans S, Pezzali N, Pieske B, Dickstein K, Fraser AG, Brutsaert DL: How to diagnose diastolic heart failure: a consensus statement on the diagnosis of heart failure with normal left ventricular ejection fraction by the Heart Failure and Echocardiography Associations of the European Society of Cardiology. Eur Heart J 2007;28: 2539-2550. 